\title{
DURABILITY OF COMPOSITE GIRDERS WITH PRESTRESSED PRECAST CONCRETE SLABS UNDER MOVING VEHICLE
}

\author{
By Hiroshi NAKAI*, Hirofumi TAKENAKA** and Hiroshi KITA***
}

\begin{abstract}
A new composite girder with prestressed precast concrete slab has been developed by the authors et. al. In applying this new composite girder to the highway bridges, there are a few unclarified problems for evaluating the fatigue behavior of composite girders, especially the cracking of precast concrete slab under the heavy traffic vehicles. In order to investigate the effects of moving vehicles on the proposed composite girders, five model girders are tested systematically under the repeated loads making use of moving vehicle apparatus. This paper reports and discusses the durability of composite girder with prestressed precast concrete slab panels through the test results.

Keywords: composite girder, prestressed precast concrete slab, repeated load by moving vehicle
\end{abstract}

\section{INTRODUCTION}

During past decade, the damages of reinforced concrete slabs (thereafter referred to as RC-slabs) in the highway bridges have been a serious problem in accordance with the increases of volume and weight of traffic vehicles. Therefore, various methods to prevent crackings of $\mathrm{RC}$-slabs and attempts for repairing or replacing the $\mathrm{RC}$-slabs have been reported by many researchers ${ }^{1)-9)}$.

Among them, a composite girder with prestressed precast concrete slabs is thought to be a useful method not only to apply the economical construction of a new type of bridge but also to repair or replace the concrete slabs of old bridges.

In applying this method to the highway bridges, however, the crackings of precast concrete slabs and the corresponding fatigue behavior of composite girders under the heavy traffic vehicles should be carefully inquired. Accordingly, the experimental study on five model girders are conducted systematically under the repeated loads by making use of a moving vehicle apparatus in order to investigate the fatigue effects of moving vehicle on the proposed type of composite girder bridges.

This paper reports the test results of strain distributions and changes of deflection in the model composite girders, slippings between steel girder and precast concrete slab as well as the propagations of cracks in the concrete slabs during the applications of repeated loads.

Then, both durability and serviceability for adopting the precast concrete slabs to the composite girders are discussed in comparisons with fatigue behavior of the ordinary RC-slab.

* Member of JSCE, Dr. Eng., Professor, Department of Civil Engineering, Osaka City University (Sugimoto 3-3-138, Sumiyoshi-ku, Osaka 558)

** Member of JSCE, M. Eng., Engineer, Harumoto Iron Works Co., Ltd. (Minami-okajima 6-20-34, Taisho-ku, Osaka 551)

*** Member of JSCE, M. Eng., Researcher, Sumitomo Metal Industries, Ltd. (Oaza-sunayama 16, Hasaki-cho, kashima-gun, Ibaragi-ken 314-02) 


\section{TEST METHOD}

\section{(1) Loading apparatus}

Fig. 1 shows the plane configration of loading apparatus, where the test girders are located at two pits $\mathrm{A}$ $(8.5 \times 8.5 \mathrm{~m})$ and $\mathrm{B}(4.5 \times 8.5 \mathrm{~m})$ in the circuit with clear width of roadway $6.0 \mathrm{~m}$. A test vehicle, equiped the DC-electric motor, is driven with the running speed, $V=15 \sim 25 \mathrm{~km} / \mathrm{h}$, around the center of this circuit through the tie bars having the radius of curvature, $12 \mathrm{~m}$, for taking the centrifugal forces of vehicle.

In this manner, the fatigue test of model girders were conducted. Fig. 2 shows the princpal dimensions and capacity of the test vehicle.

\section{(2) Model girders}

Five model girders, G-1 through G-5, were fabricated, in which model girder, G-1, was an almost full size model girder to investigate the fatigue behavior throughout the real composite girder bridge built by using the precast concrete slab.

On the other hand, the propagations of crack in concrete slabs were examined by much more small model girders, G-2 through G-5, where the model girder, G-2, was provided with the conventional RC-slab for the sake of comparisons of the cracking patterns with those of precast concrete slab.

For the materials of concrete slab, normal and expansive cement were used alternatively. The boundary conditions of concrete slab panel in the transeverse direction of model girders are determined as continuously or simply supported at the interior steel girder in the model girder, G-1, whereas those in the remaining model girders, G-2 through G-5, being determined as simply supported.

These slabs were designed according to the design criteria of Japanese Specification for Highway Bridges (hereafter referred to as JSHB) by assuming wheel load intensity, $P=49.0 \mathrm{kN}$, of the test vehicle in Fig. 2 (JSHB specifies $P=78.4 \mathrm{kN}$ ) and the thickness of concrete slab of model girder, G-1, was determined as $160 \mathrm{~mm}$ (equivalent to the minimum required thickness of JSHB). While, those of model girders, G-2 through G-5, were taken as $100 \mathrm{~mm}$. The stress level of main reinforcement bars with diameter, $\phi-16 \mathrm{~mm}$, and pitch, $150 \mathrm{~mm}$, in the transverse direction of model girder, G-1, is, of course, checked to fall within the actual stress ranges of composite girder bridges and the stress level is determined as $\sigma_{s}=90 \mathrm{Mpa}$. The stress level of model girders, G-2 through G-5, with main reinforcement bars, $\phi-13 \mathrm{~mm}$, spaced with $150 \mathrm{~mm}$ pitch, is nearly equal to twice value of G-1 so as to predominate the crackings of concrete slab.

The precast concrete slabs of model girders G-1 and G-3 through G-5, were prestressed in the longitudinal direction of the steel girders by posttensioning method.

In model girders, G-1 and G-5, the prestressed forces in the transverse direction of model girder were introduced through PC-bars with diameters, $\phi-9.2 \mathrm{~mm}$ and $\phi-7.4 \mathrm{~mm}$, by the pretensioning method, respectively.



Fig. 1 Plane Configuration of Loading Apparatus.
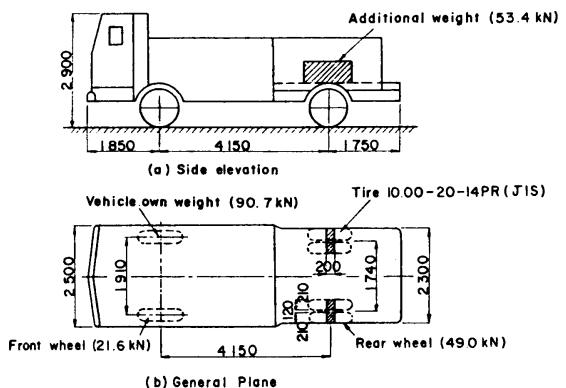

Fig. 2 Detail of Test Vehicle (Dimension in $\mathrm{mm}$ ). 
Table 1 Details of Concrete Slabs for Model Girders.

\begin{tabular}{|c|c|c|c|c|c|c|c|c|c|c|}
\hline \multirow{2}{*}{$\begin{array}{l}\text { Model } \\
\text { girder }\end{array}$} & \multirow{2}{*}{$\begin{array}{l}\text { Type of } \\
\text { concrete } \\
\text { slab }\end{array}$} & \multirow{2}{*}{$\begin{array}{l}\text { Boundary } \\
\text { cond } 1 \text { tion } \\
\text { in trans. } \\
\text { direction }\end{array}$} & \multirow{2}{*}{$\begin{array}{c}\text { Number } \\
\text { of } \\
\text { panels }\end{array}$} & \multirow{2}{*}{$\begin{array}{l}\text { Thickness } \\
\text { of } \\
\text { concrete } \\
\text { slab }(\mathrm{mm})\end{array}$} & \multirow{2}{*}{$\begin{array}{l}\text { width } \\
\text { of } \\
\text { concrete } \\
\text { slab }(\mathrm{cm})\end{array}$} & \multicolumn{3}{|c|}{ Used concrete } & \multicolumn{2}{|c|}{$\begin{array}{l}\text { Residual prestress } \\
\text { in concrete slab(tAPa) }\end{array}$} \\
\hline & & & & & & $\begin{array}{l}\text { Mix pro- } \\
\text { portion }\end{array}$ & Quality & $\begin{array}{c}\text { Strength } \\
(\mathrm{MPa})\end{array}$ & $\begin{array}{l}\text { in concr } \\
\text { Longi- } \\
\text { tudinal } \\
\end{array}$ & $\begin{array}{l}\text { slab(tAPa) } \\
\text { Trans- } \\
\text { verse }\end{array}$ \\
\hline \multirow{3}{*}{ G-1 } & \multirow{3}{*}{$\begin{array}{l}\text { Full size } \\
\text { precast } \\
\text { concrete } \\
\text { slab }\end{array}$} & \multirow{3}{*}{\begin{tabular}{|l|} 
Cont inuous \\
panel \\
Simply \\
supported \\
panel
\end{tabular}} & 4 & \multirow{3}{*}{160} & \multirow{3}{*}{$\frac{500}{250}$} & A & \multirow{2}{*}{$\begin{array}{l}\mathrm{NC}^{*} \\
\text { and } \\
\mathrm{EC}^{* *}\end{array}$} & 42.2 & \multirow{3}{*}{3.0} & \multirow{2}{*}{0} \\
\hline & & & 4 & & & $B$ & & 42.2 & & \\
\hline & & & 4 & & & C & NC & 52.0 & & 4.2 \\
\hline G-2 & $\begin{array}{l}\text { Conven- } \\
\text { t Ional } \\
\text { RC-slab }\end{array}$ & - & - & 100 & 180 & D & NC & 29.8 & - & - \\
\hline \multirow{2}{*}{ G-3 } & \multirow{2}{*}{$\begin{array}{l}\text { Completely } \\
\text { released } \\
\text { precast } \\
\text { concrete } \\
\text { slab }\end{array}$} & \multirow{2}{*}{$\begin{array}{l}\text { Simply } \\
\text { supported } \\
\text { panel }\end{array}$} & 2 & \multirow{2}{*}{100} & \multirow{2}{*}{180} & $A$ and $B$ & $\mathrm{NC}$ and $\mathrm{EC}$ & 42.2 & \multirow{2}{*}{0} & \multirow{2}{*}{0} \\
\hline & & & 2 & & & c & NC & 52.0 & & \\
\hline \multirow{2}{*}{ G-4 } & \multirow{2}{*}{$\begin{array}{l}\text { Partially } \\
\text { released } \\
\text { precast } \\
\text { concrete } \\
\text { siab }\end{array}$} & \multirow{2}{*}{$\begin{array}{l}\text { Simply } \\
\text { supported } \\
\text { panel }\end{array}$} & 2 & \multirow{2}{*}{100} & \multirow{2}{*}{180} & $A$ and $B$ & $\mathrm{NC}$ and $\mathrm{EC}$ & 42.2 & \multirow{2}{*}{3.0} & \multirow{2}{*}{0} \\
\hline & & & 2 & & & c & NC & 52.0 & & \\
\hline G-5 & $\begin{array}{l}\text { Two-direc- } \\
\text { tionaliy } \\
\text { prestressed } \\
\text { precast } \\
\text { concrete } \\
\text { slab }\end{array}$ & $\begin{array}{l}\text { Simply } \\
\text { supported } \\
\text { panel }\end{array}$ & 4 & 100 & 180 & C & NC & 52,0 & 3.0 & 5.3 \\
\hline
\end{tabular}

Remarks: * NC : Normal Concrete. ** EC : Expansive Concrete

Table 2 Concrete Mix Proportion.

\begin{tabular}{|c|c|c|c|c|c|c|c|c|c|c|c|c|}
\hline \multirow[t]{2}{*}{ Cement } & \multirow[t]{2}{*}{ Type } & \multirow{2}{*}{$\begin{array}{l}\text { Design } \\
\text { strength } \\
\text { (MPa) }\end{array}$} & \multicolumn{5}{|c|}{$\begin{array}{l}\text { Unit content } \\
\left(\mathrm{N} / \mathrm{m}^{3}\right)\end{array}$} & \multirow{2}{*}{$\begin{array}{l}w / c \\
(x)\end{array}$} & \multirow{2}{*}{$\begin{array}{l}S / A \\
(x)\end{array}$} & \multirow{2}{*}{$\begin{array}{l}\text { Maxi mum } \\
\text { aggregate } \\
\text { size } \\
(\mathrm{mm})\end{array}$} & \multirow{2}{*}{$\begin{array}{l}\text { Air } \\
\text { entraining } \\
\text { material } \\
(x)\end{array}$} & \multirow{2}{*}{$\begin{array}{r}\text { S1 ump } \\
(\mathrm{cm})\end{array}$} \\
\hline & & & $w$ & c & $\mathrm{s}$ & G & M & & & & & \\
\hline Expansive & A & 39.2 & 1441 & 2940 & 7350 & 11446 & $490^{*}$ & 42 & 40 & 20 & $2 \pm 1$ & $6 \pm 1.5$ \\
\hline \multirow{3}{*}{ Normal } & B & 39.2 & 1441 & 3430 & 7350 & 11446 & 0 & 42 & 40 & 20 & $2 \pm 1$ & $6 \pm 1.5$ \\
\hline & C & 44.1 & 1490 & 3920 & 6684 & 11319 & $102^{* *}$ & 38 & 38 & 20 & $2 \pm 1$ & $6 \pm 1.5$ \\
\hline & D & 29.4 & 1421 & 3273 & 10800 & 7370 & $34^{* * *}$ & 43 & 40 & 20 & 4 & 8 \\
\hline
\end{tabular}

*:Expansive admixture(onoda Expan), ** and ***:Admixture (Pozzolith NL-4000 and No.10L)

The details of concrete slab are listed in Table 1.

Table 2 shows the mix proportions of concrete materials for the precast concrete slab panels and reinforced concrete slab. In type $A$ and types $B$ through $D$, expansive and normal concrete were used, respectively. Type $\mathrm{D}$ is designed for the reinforced concrete slab at the construction site, where the strength of concrete is designed as $\sigma_{C K}=29.4 \mathrm{Mpa}$ on the basis of real situation in highway bridges.

Then, their properties are detailed in Table 1.

Figs. 3 and 4 illustrate the details of precast concrete slab panels of the model girders, G-1 and G-5, respectively. The forms for precast concrete slab panels were fabricated by using the steel plates for the sake of keeping the dimensions of the concrete panels as much as accurate. Concrete was encased into the forms after the built-up of the reinforcements with diameter, $16 \mathrm{~mm}$ or $13 \mathrm{~mm}$, and the spiral sheaths



(a) Cross-section

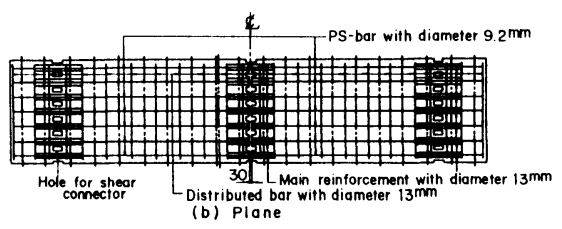

Fig. 3 Detail of Precast Concrete Slab Panel (G-1).

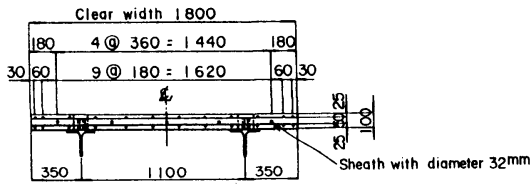

(a) Cross-section



(b) Plane

Fig. 4 Detail of Precast Concrete Slab Panel (G-5). 


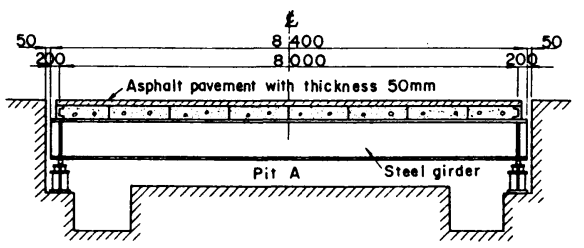

(a) Side - elavation

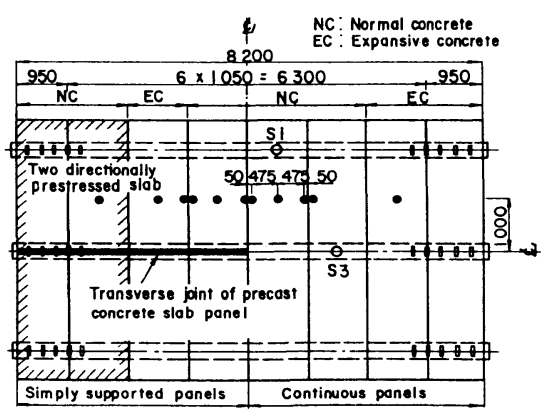

(b) Plane

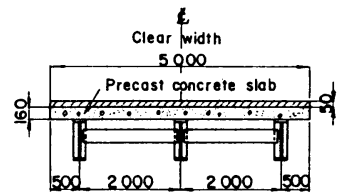

(c) Cross - section

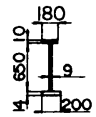

(d) Detail of steel girder

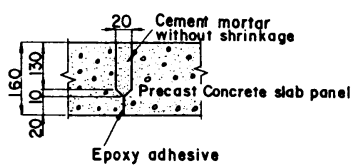

(e) Detail of joint between panels

Meosuring point

- : Deflection of slab

0 : Strain distribution in steel girder

Fig. 5 Details of Model Girder G-1 (Dimension in $\mathrm{mm}$ ).

having diameter, $35 \mathrm{~mm}$ or $32 \mathrm{~mm}$, were distributed as shown in Figs. 3 and 4 .

The transverse prestress forces in the precast concrete slab panels were introduced by the pretensioning method by using PS-bars, Class D and No. 1, which are specified in JIS G 3109-1977, with diameter, $\phi-9.2 \mathrm{~mm}$ or $\phi-7.4 \mathrm{~mm}$. Table 3 shows the yield stress, design pretensioning stress and applied pretensioning forces of their PS-bars. The prestressings of precast concrete slab panels were carried out after the strength of concrete was resulted in more than $34.3 \mathrm{Mpa}$.

Table 3 Pretensioning Force of PS-bar.

\begin{tabular}{|l|c|c|c|c|}
\hline $\begin{array}{l}\text { Model } \\
\text { girder }\end{array}$ & $\begin{array}{c}\text { Di ameter } \\
(\mathrm{mm})\end{array}$ & $\begin{array}{c}\text { Yield } \\
\text { stress } \\
\text { (MPa) }\end{array}$ & $\begin{array}{c}\text { Design pre- } \\
\text { tensioning } \\
\text { stress } \\
\text { (MPa) }\end{array}$ & $\begin{array}{c}\text { Appli ed pre- } \\
\text { tensioni } \\
\text { force } \\
\text { (KN) }\end{array}$ \\
\hline$G-1$ & 9.2 & 1274 & 784 & 51.7 \\
\hline$G-5$ & 7.4 & 1274 & 980 & 40.4 \\
\hline
\end{tabular}

a) Detail of model girder G-1

Fig. 5 shows the details of model girder G-1 of which three steel girders are fabricated by the mild steel SS-41 (allowable unit stress, $\sigma_{t a}=$ 137. 2 Mpa) with thickness 9,10 and $14 \mathrm{~mm}$, The span length, $l=8.0 \mathrm{~m}$, with both the ends simply supported and the girder depth, $h=65 \mathrm{~cm}$, were determined so as to limit the maximum stress of steel girder is less than $0.25 \sigma_{t a}$.

The precast concrete slabs, detailed in Table 1, were connected to steel girders through pairs of shear connectors having dimensions, $\phi-19 \times$ $110 \mathrm{~mm}$, and pitch, $150 \mathrm{~mm}$, after the introduction of prestress force $\left(\sigma_{c}=7.8 \mathrm{Mpa}\right)$ to the longitudinal direction of precast concrete slab by twenty PC-wires with diameter, $\phi-19.3 \mathrm{~mm}$, and hydraulic jack. Thereafter, these prestress forces were released down to $\sigma_{c}=3.0 \mathrm{Mpa}$, thus the model girder was completed. The test was con-

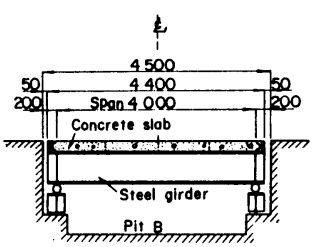

(c) Cross-section of model girder

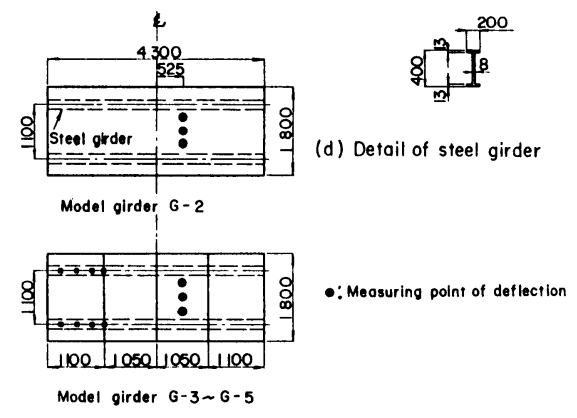

(b) Plane

Fig. 6 Details of Model Girders G-2 through G-5 (Dimension in $\mathrm{mm}$ ). (a) Side - elevation 
ducted by setting this girder into the pit A (see Fig.1).

b) Details of model girders G-2 through G-5

The model girders, G-2 through G-5, were fabricated in a manner simllar to the above, except the steel girders were made of H-beam with the dimensions, $400 \times 200 \times 13 \times 8 \mathrm{~mm}$, and the shear connectors, $\phi-16$ $\times 80 \mathrm{~mm}$, having pitch $150 \mathrm{~mm}$. The concrete slabs were composed of ordinary RC-slab, precast concrete slab without or with residual prestress forces in the longitudinal and the transverse directions in model girders, G-2 through G-5, as detailed in Table 1 and Fig. 6 . Two model girders were situated simultaneously in the test pit B (see Fig. 1).

(3) Measuring method

The model girders, G-1, G-2 and G-3 or G-4 through G-5, were located at the pits A and B, respectively, as shown in Fig. 1. A test vehicle was driven with the running speed, $V \simeq 20 \mathrm{~km} / \mathrm{h}$. Measuring was carried out by loading the rear wheel of test vehicle on the model girders statically after the appropriate running cycles.

Table 4 shows the running cycles and the corresponding rear wheel load at measuring of which points are shown in Figs. $5 \sim 6$.

\section{TEST RESULTS AND THEIR DISCUSSIONS}

\section{(1) Test results of model girder G-1}

Strain distributions and deflections in the model girder G-1 during the erections were measured and quite well results are recognized as it is reported by reference 10). Therefore, the fundamentally important behavior due to the applications of moving vehicle are only explained and discussed herein as follows ;

a) Variations of strain distributions

The strain distributions at the measuring section S 3 (see Fig. 5) are plotted as shown in Fig. 7. These measured values do not change, even in the case where the running cycle increase to $N=500,000$. Accordingly, the strain distributions during the tests always coincide well with the elementary beam theory.

b) Variations of slip between concrete slab and steel girder

Table 4 Running Cycle and Corresponding Rear Wheel Load at Measuring.

\begin{tabular}{|c|c|c|c|c|c|}
\hline \multicolumn{2}{|c|}{$G-1$} & \multicolumn{2}{|c|}{$G-2$ and G-3 } & \multicolumn{2}{|c|}{ G-4 and G-5 } \\
\hline $\begin{array}{l}\text { Running } \\
\text { cycle }\end{array}$ & $\begin{array}{l}\text { Rear wheel } \\
\text { load }(\mathrm{kN})\end{array}$ & $\begin{array}{l}\text { Running } \\
\text { cycle }\end{array}$ & $\begin{array}{l}\text { Rear wheel } \\
\text { load }(\mathrm{kN})\end{array}$ & $\begin{array}{l}\text { Running } \\
\text { cycle }\end{array}$ & $\begin{array}{l}\text { Rear wheel } \\
\text { load (kN) }\end{array}$ \\
\hline $\begin{array}{r}14000 \\
88000 \\
145000 \\
190000 \\
250000 \\
295000 \\
350000 \\
500000 \\
500001 \\
539000 \\
625000\end{array}$ & $\begin{array}{l}49 \\
49 \\
49 \\
49 \\
49 \\
49 \\
49 \\
49 \\
49 \\
73.5 \\
73.5 \\
73.5\end{array}$ & 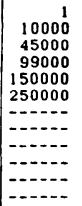 & $\begin{array}{l}49 \\
49 \\
49 \\
49 \\
49 \\
49 \\
-- \\
-- \\
-- \\
-- \\
--\end{array}$ & $\begin{array}{r}10000 \\
77000 \\
133100 \\
185000 \\
250000 \\
250001 \\
289000 \\
375000 \\
-0.0 \\
-\end{array}$ & $\begin{array}{l}49 \\
49 \\
49 \\
49 \\
49 \\
49 \\
73.5 \\
73.5 \\
73.5 \\
--.- \\
-.- \\
----\end{array}$ \\
\hline
\end{tabular}

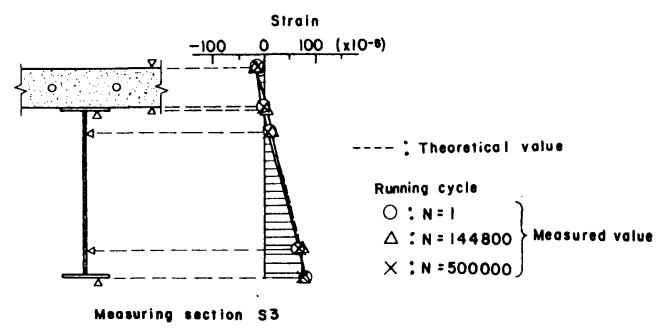

Fig. 7 Variations of Strain in Composite Girder.

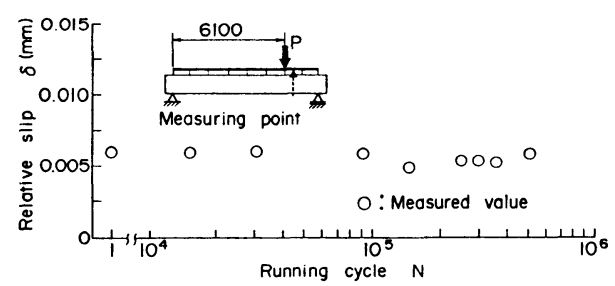

Fig. 8 Variations of Slip between Slab and Girder.

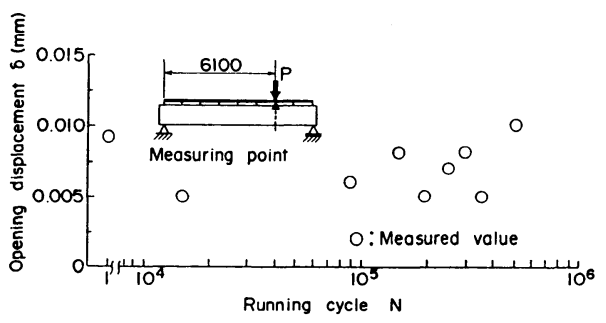

Fig. 9 Variations of Opening Displacement at Joint of Precast Concrete Slab (Lange Scale Girder). 
The relative slip between concrete slab and steel girder is within the range of $0.006 \mathrm{~mm}$, being very small quantity after the last running test as illustrated in Fig. 8. Combining the above and this facts, it seems that the precast concrete slabs are completely connected to the steel girders.

c) Opening displacement between precast concrete slab panels

The precast concrete slab panels are combined together by the method as detailed in Fig. 5 e). For these joints, the opening displacement were measured at one of a lower surface of precast concrete slab. This results is plotted as shown in Fig. 9. It is observed from this figure that the test results fluctuate from $0.005 \mathrm{~mm}$ to $0.01 \mathrm{~mm}$, but the maximum value is very small and do not influence upon the durability of composite girders built by precast concrete slab.

d) Deflection of concrete slab

The variations of deflection in a precast concrete slab at the mid-section along two steel girders are plotted as shown in Fig. 10. It can be seen from this figure that the deflection of slab remains within constant value with slight fluctuation at the joints adjacent to the precast concrete slab. In this figure, an analytical results by FEM analysis by using elastic elements connected to the border of the orthotropic plate elements, is also plotted by a dotted line. Through the comparisons of test results with the theoretical predictions, it is confirmed that the residual prestress forces in the precast concrete slabs can effectively be holded up to the running cycle $N=500,000$.

e) Crack in precast concrete slab

In the model girder G-1, only one crack was observed in the continuous precast concrete slab panels near the interior steel girder at the running cycle $N=230,000$ as illustrated in Fig. 11. However, another cracks do not propagate up to the running cycle $N=500,000$.

Although various type of precast concrete slabs are utilized in this model girder, their qualities do not influence upon the propagations of crack, but their boundary conditions and methods to prestress the concrete slab will be an important factor.

(2) Test results of model girders G-2 through G-5

In the model girders, G 2 through G-5, the propagation of cracking in the concrete slabs and the corresponding deflections are mainly investigated up to the running cycle $N=250,000$. These results can be predicated as follows;

a) Opening displacement between precast concrete slab panels

Fig. 12 shows the opening displacement at joints of precast concrete slab panels concerning the model girders, G-3 through G-5. The values of the opening displacements are almost constant and small in accordance with increase of the running cycle.

From this result, it seems that the joints between precast concrete slab panels are not damaged after repeated loading by the moving vehicle. And the maximum value of opening displacement is equal to the theoretical stretch of lower surface of slab as a body caused by the bending moment at loading position.

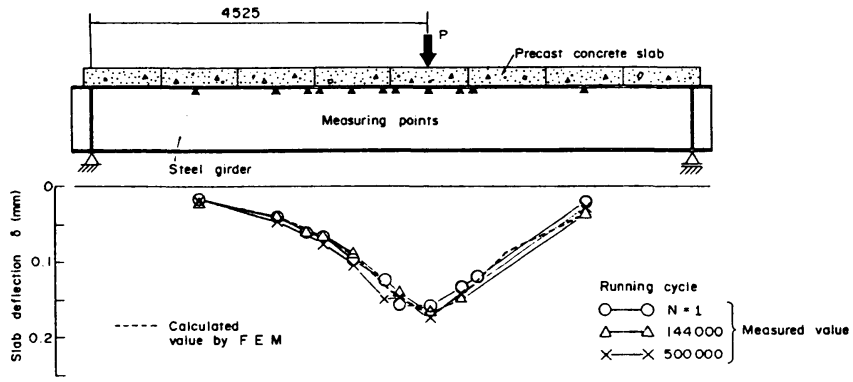

Fig. 10 Variations of Displacement of Precast Concrete Slab (Large Scale Model Girder).

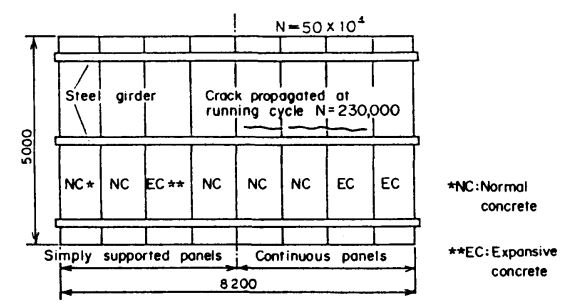

Fig. 11 Initiation of Crack in Model Girder G-1 (Dimension in $\mathrm{mm}$ ). 
b) Propagations of crack in concrete slab

Fig. 13 shows the patterns of cracking at each model girders on the reverse surface of concrete slab without model girder, G-5. Observing this figure, the transverse and longitudinal cracks of RC-slab in the model girder, G-2, are remarkable and the propagations of cracks have a similar tendency to coincide with the ordinary composite girder bridges having RC-slab. On the other hand, the transverse cracks in the model girders, G-3 and G-4, are not so significant and the longitudinal cracks in the latter is the less than the former. This might be caused by the residual prestress in the precast concrete slab. The cracks of model girder, G-5, with prestressed precast concrete slab in two directions were not observed. Then, their figure is omitted herein.



(a) Model girder $\mathrm{G}-3$

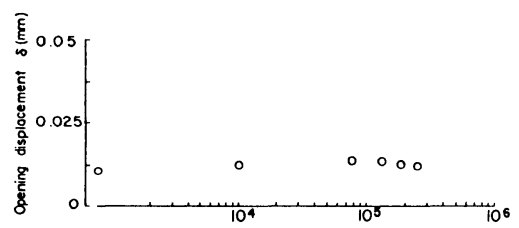

(b) Model girder G-4

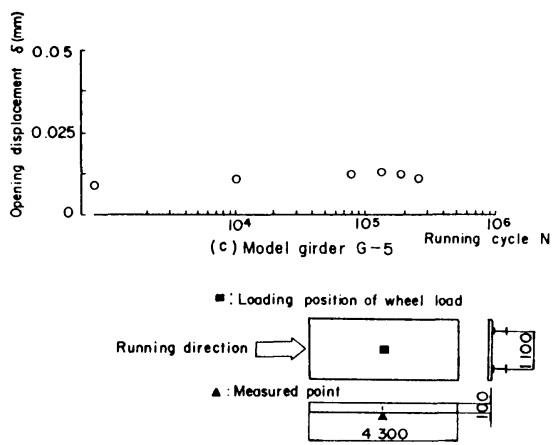

Fig. 12 Variations of Opening Displacement at joint of Precast Concrete Slab (Small Scale Model Girder).
It is worth to note from these test results that the transverse cracking of precast concrete slabs can be prevented by retaining the approiate prestress forces in their longitudinal direction.

For the composite girder subjected to heavy traffic vehicles, it is a powerful method to design them as prestressed precast concrete slab in two directions.

c) Variations of deflection in concrete slab

Figs. 14 and 15 show the variations of deflection for the concrete slabs in the transverse and the

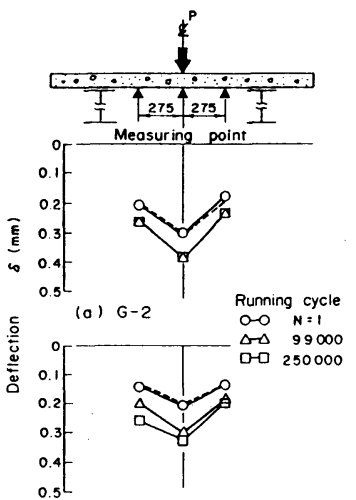

(b) $6-3$

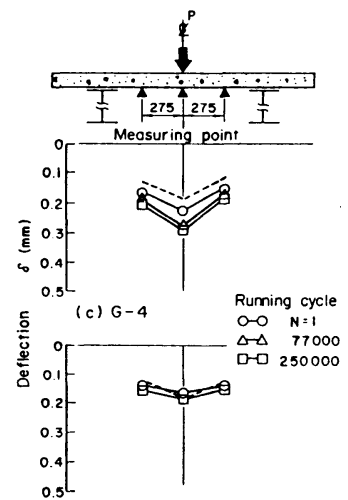

(d) G-5
Fig. 14 Variations of Deflection for Concrete Slabs in Model Girders G-2 G-5.
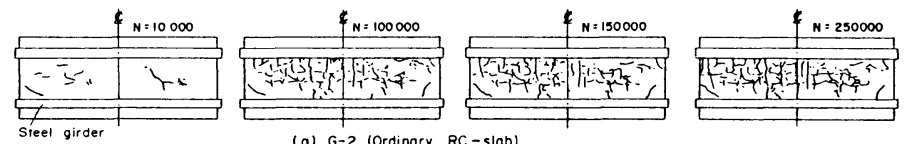

(a) G-2 (Ordinary RC-slab)
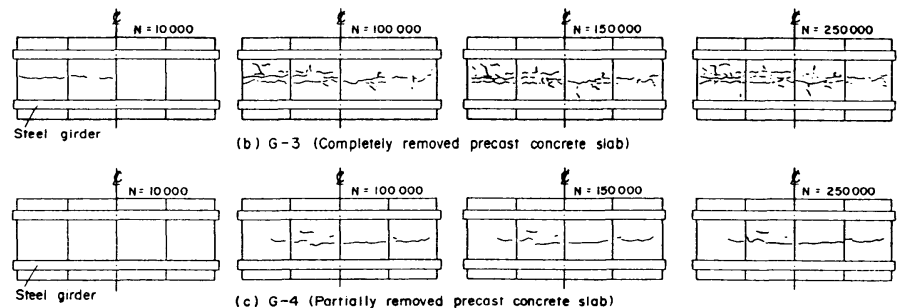

(b) G-3 (Completely removed precost concrete siab)
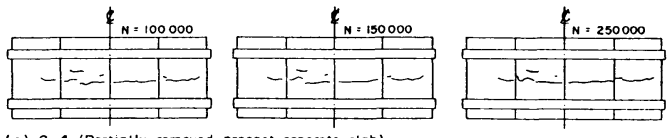

(c) G-4 (Partially removed precast concrete slab)

Fig. 13 Propagations of Crack for Model Girders G-2 G-4. 



Fig. 15 Variations of Deflection for Precast Concrete Slab (Small Scale Model Girders).

longitudinal directions of steel girders.

The deflection of conventional RC-slab is gradually increased in accordance with the accumulations of running cycles. The similar tendency is observed in the case where the prestress forces are fully released in the precast concrete slab. Whereas, the variations of deflection are not noticeable in the case where a certain prestress forces are retained in the precast concrete slab. Furthermore, the deflections do not change in the case of prestressed precast concrete slab in two directions.

\section{CONCLUSION}

This paper presents the experimental study on the fatigue tests of composite girders by using precast concrete slabs through a moving vehicle apparatus. The main conclusions obtained from the test results are summarized as follows;

(1) The composite girders built by using precast concrete slab behave as a complete composite beam with sufficient rigidity even in the case of moving vehicles.

(2) The continuity conditions of axial displacement at the joints of precast concrete slab are held due to the prestress force, although the precast concrete slab is composed of a few discontinuous precast concrete slab panels.

( 3 ) The cracking of concrete slabs is significantly prevented through the introductions of appropriate prestress forces rather than the improvements of strength and quality of concrete materials.

(4) The adjustments of longitudinal prestress forces in the precast concrete slab control not only transverse cracking, but also longitudinal cracking.

(5) It is preferable to utilize two-directionally prestressed concrete slabs in the case where the concrete slab undergoes the extremely heavy traffic flows.

\section{ACKNOWLEDGEMENTS}

In executing a series of experimental studies, the authors would like to acknowledge the valuable supports obtained from Mr. S. Yamakawa, Vice Manager of Central Research Laboratories, Sumitomo 
Metal Industries, Ltd. and Mr. H. Kishida, Director of Bridge Design Division, Harumoto Iron Works Co. , Ltd.

\section{REFERENCES}

1) PCI Bridge Committee : Tentative Design and Construction Specifications for Bridge Deck Panels, Jour. of the Prestressed Concrete Institute, Vol.23, pp. 32 39, January-February 1978.

2) Fagundo, E. E. and Hays, Jr. C. O. : Experimental and Analytical Evaluation of Causes of Cracking in Precast Panel Highway Bridges, ISA Transactions, Vol. 23, No.1, pp. 1 9

3) Hanshin Expressway Public Corporation and Japanese Society of Material Engineers : Strength of Precast Concrete Composite Deck Panel, Research Report, March 1982.

4) Subcommittee for Investigation of Technical Progress, Committee on Steel Structures : State of the Art of Concrete Slabs in Steel Highway Bridges, Journal of JSCE, Vol. 70, No. 2, pp. 57 64, February 1985.

5) Metropolitan Expressway Association : Research on Design and Construction of Reinforcing for Slabs, Research Report No. 1, March 1980.

6) Kujirai, H. : Loading Test of Concrete Slabs Reinforced by Added Stringers, The Bridge and Foundation Engineering, Vol. 17, No. 8, pp. 121 128, August 1983.

7) Sonoda, T. : Repairing and Reinforcing of Reinforced Concrete Slabs, The Bridge and Foundation Engineering, Vol. 17, No. 8, pp. 129 133, August 1983.

8) Japanese Society of Civil Engineers, Kansai Branch : Study on Design Method of Steel-Concrete Composite Slabs in Highway Bridge, Report of Joint Research Group, May 1984.

9) Slavis, C. : Precast Concrete Deck Modules for Bridge Deck Reconstruction, Journal of the Prestressed Concreted Institute, Vol. 28, pp. $120 \sim 135,1983$.

10) Takenaka, H., Kishida, H. and Nakai, H. : A Study on New Composite Girder using Prestressed Precast Concrete Slab by PPCS Method, Der Stahlbau, s. 165 174, Juni 1986. 